\title{
Uzaktan Eğitim Sürecinde Öğretmenlerin Teknoloji Kullanım Durumlarının İncelenmesi
}

DOI: $10.26466 /$ opus.903870

$*$

\author{
Mehmet Başaran* - Irmak Gül Ülger*- Merve Demirtaş ${ }^{* * *}$ \\ Elif Kara $^{* * * *}$ - Ceylan Geyik ${ }^{* * * *}$ - Ömer Faruk Vural ${ }^{* * * * * *}$ \\ * Dr. Öğr. Üyesi, Gaziantep Üniversitesi, Eğitim Fakültesi, Gaziantep/Türkiye \\ E-Posta: mehmetbasaran@outlook.com ORCID: 0000-0003-1871-520X \\ ** Öğretmen, Şehit Ümüt Özcan İlkokulu, Gaziantep/Türkiye \\ E-Posta: ulgergull@gmail.com \\ ORCID: 0000-0003-4799-5802 \\ *** Öğretmen, İpekyolu Ortaokulu, Şanlıurfa/Türkiye \\ E-Posta: mervedemirtas2010@hotmail.com ORCID: 0000-0001-6994-7364 \\ **** Uzman, Gaziantep Üniversitesi, Gaziantep/Türkiye \\ E-Posta melifkara@hotmail.com ORCID: 0000-0002-1854-2508 \\ ***** Öğretmen, Merveşehir Ortaokulu, Gaziantep/Türkiye \\ E-Posta geyikceylan71@gmail.com ORCID: 0000-0001-5013-964X \\ *******Doç. Dr., Sakarya Üniversitesi, Eğitim Fakültesi, Sakarya/Türkiye \\ E-Posta omervural@sakarya.edu.tr ORCID: 0000-0002-1520-3762
}

Öz

Bu araştırmanın amacı, günümüze kadar zorunluluk haline gelmeyen eğitimde teknoloji kullanımının, Covid-19 pandemisi sonrasında zorunluluk haline gelmesiyle birlikte öğretmenlerin yaşadığı sorunlar, teknolojik yeterlilikleri, teknolojiyi kullanma becerileri ve hazır bulunuşluklarının ne düzeyde olduğunu ortaya koymaktır. Çalışma 2020-2021 eğitim öğretim yılında ilkokul, ortaokul ve liselerde görev yapan farkl branştaki 20 öğretmen ile yürütülmüştür. Çalışma nitel olarak yürütülmüş ve araştırmacılar tarafından hazırlanan yarı yapılandırılmış bir görüşme formu ile veriler toplanmıştır. Verilerin çözümlenmesinde ise içerik analizinden yararlanılmıştır. Öğretmenler uzaktan eğitim sürecinin başlarında Zoom vb uzaktan eğitim araçlarının kullanımında zorluk yaşadıklarını dile getirmişlerdir. Öğretmenler basit düzeyde sunum ve görsel materyal hazırladıklarını, gerektiğgi durumlarda derslerinde hazır sunum kullandıklarını ve Web 2.0 araçların ise kullanmadıklarını belirtmişlerdir. Öğretmenler uzaktan eğitimde işlenen derslerin açık, net, anlaşılır ve verimli işlendiğini belirtmiştir. Öğretmenlerin teknolojik yeterliliklerinin eksik olduğu gözlenmiş ve teknoloji kullanımı ile ilgili hizmet içi eğitim almadıkları belirlenmiştir. Öğretmenlerin teknoloji kullanımına ve uzaktan eğitim araçlarını kullanmaya yönelik hizmet içi eğitim almaları faydah olabilir.

Anahtar Kelimeler: Uzaktan eğitim, öğretmenlerin teknolojik yeterlilikleri, Covid-19 pandemisi 


\title{
Investigation of Teachers' Use of Technology in the Distance Education Process
}

\begin{abstract}
The aim of this study is to reveal the problems faced by teachers, technological competencies, technology use skills, and readiness as the use of technology in education, which has not become a necessity until today, has become a necessity after the Covid-19 pandemic. The study was carried out with 20 teachers from different primary, secondary and high schools in the 2020-2021 academic year. The study was conducted as qualitative research, and data were collected with a semi-structured interview form prepared by the researchers. Content analysis was used to analyze the data. Teachers stated that they had difficulties using distance education tools such as Zoom at the beginning of the distance education process. Teachers stated that they prepared simple level presentations and visual materials, used prepared presentations in their lessons when necessary, and did not use Web 2.0 tools. Teachers stated that the lessons taught in distance education are taught understandably and efficiently. It was observed that the teachers' technological competencies were lacking, and they did not receive in-service training on technology use. It may be beneficial for teachers to receive in-service training on using technology and using distance education tools.
\end{abstract}

Keywords: Distance education, technological competence of teachers, Covid-19 pandemic 


\section{Giriş}

21. yüzyıl dünyasında teknoloji hayatın her alanında kullanılmakta ve hızla değişime uğramaktadır. Özellikle bilgi ve iletişim teknolojilerinde gerçekleşen değişimler her alanı olduğu gibi eğitim sistemini de etkilemektedir. Teknolojideki ilerlemeler eğitim sisteminin ve öğretmenlerin mesleki becerilerinin değişmesini mecburi kılmaktadır. Öğretmen ve öğrencilerin bu yeniliklere uyum sağlaması, bilgiye ulaşma için farklı öğretim ortamları düzenlenmesi gereklidir. Bu nedenle teknoloji öğrenme sürecinin vazgeçilmez bir parçası olmuştur (Kurbanoğlu ve Akkoyunlu, 2002). Bilgi ve iletişim teknolojileri öğrenme ve öğretme süreci boyunca kullanılmaktadır ve bu da sürecin verimliliğini arttırmaktadır (Akkoyunlu, 1995).

Teknolojideki yenilikleri takip etmek ve bunları günlük yaşantımızda doğru bir şekilde uygulayabilmek herkesin kazanması gereken bir beceridir. Eğer bu beceriye öğretmenler sahip değilse öğrencilere bu becerilerin kazandırılması çok zordur (Kaya, 2006). Öğretmenlerin teknolojiyi etkili olarak kullanmaları ve öğrenciye model olmaları için bilgisayar konusunda bilgi sahibi olmaları ve bu konuda kendilerini yeterli hissetmeleri gerekir (Kurbanoğlu ve Akkoyunlu, 2002).

Günümüzde bilgi ve iletişim teknolojileri hem sınıf ortamlarında hem de uzaktan eğitim sürecinde kullanılmaktadır. Uzaktan eğitim; sınıf içi etkinliklerin yapılamadığı durumlarda, öğretmen ile öğrenciler arasında çeşitli ortamlar yoluyla yapılan öğretme yöntemidir (Alkan, 1981). Uzaktan eğitim geçmişten günümüze mektupla, radyo ve televizyon aracılığıyla, bilgisayar ve internet yoluyla gelişerek gelmiştir. Günümüzde uzaktan eğitim en çok web tabanlı olarak yapılmaktadır (Dinçer, 2016). Ülkemizde de özellikle 2000'li yılların başlarından itibaren teknolojik gelişmelerle uzaktan eğitim olanakları artmış ve birçok öğrenciye ulaşarak eğitimin bir parçası olmuştur (Bozkurt, 2017).

Özellikle dünyada yaşanan Covid-19 salgını nedeniyle uzaktan eğitim kullanımı yaygınlaşmıştır. Çin'in Wuhan şehrinde 2019 yılının aralık ayında ilk kez görülen Covid-19 salgını, kısa sürede tüm dünya ülkelerini olumsuz etki altına almış pandemidir. Bu salgın tüm gelişmiş veya gelişmekte olan ülkeleri; sağlık, taşımacılık, ticaret, tarım, bankacılık ve finans, eğitim gibi sektörler başta olmak üzere birçok sektörde etkisi altına almış, sonuçları ağır olan birtakım sorunlarla yüz yüze bırakmıştır (Ertuğ, 2020). 
Eğitime etkisine bakacak olursak bulaşıcılık ve ölüm risklerini yüksek derecede taşıdığından COVID-19 salgını tüm dünya ülkelerinde bir korku ve panik havası yaratmış, "evde kalın" çağrısı ile salgını kontrol altına almak isteyen tüm diğer ülkeler gibi Türkiye de eğitim sürecine geçici süre ara vermiştir ve bunun yerine öğrencilerin teknolojik araçlar ile uzaktan eğitim şeklinde devam etmeleri tüm ülkelerce karara bağlanmıştır (Üstün ve Özçiftçi, 2020).

Bu süreçte birçok öğretmen uzaktan eğitimin nasıl yürütüleceğine dair tedirginlikler yaşamış ve uzaktan eğitim sürecinde birtakım zorluklar çekmiştir. Bu sebeple, öğretmen yetiştiren kurumlarda sürekli ve teknoloji ile entegre olmuş kursların, öğretmenlerin teknoloji bilgilerini en verimli ve etkili şekilde kullanabilmesi ve değişen çağa ayak uydurabilmesi için öğretmenleri yetiştirmeleri gerekliliği vurgulanmıştır (Akpınar, 2003).

Covid-19 salgını bizlere göstermiştir ki, eğitim ve teknoloji her zaman iç içe olmalı; öğretmenler her an bu bilgi teknolojileri kullanımına açık ve hazır bulunmalıdır. Ancak; Türkiye'deki eğitim fakültelerine baktığımızda, öğretmeni çağın bilgi teknolojileri kullanımına hazırlamada yetersiz olduğu görülmektedir (Göktaş, Yıldırım ve Yıldırım, 2010). Okullarda çalışmaya devam eden öğretmenlerin ve hala öğrenimine devam etmekte olan öğretmen adaylarının sürekli gelişen ve değişen teknolojiye açık olması, çağın teknolojik bilgi ve becerilerini kazanması ve bilgiyi öğrenciye aktarma sürecinde teknoloji kullanımını benimsemesi gerekmektedir (Keleş ve Güntepe, 2018). Kendilerini ve öğrencilerini çağın teknoloji ile entegre edilmiş eğitim sistemine ayak uyduracak şekilde yetiştirecek olan öğretmenlerin, teknoloji tabanlı eğitim sistemini benimseyerek, bilgiyi öğrencilerine en güncel şekliyle aktarması için Millî Eğitim Bakanlığı'ndan alacakları hizmet içi eğitimlerle kendilerini sürekli yenilemeleri ve geliştirmeleri gerekmektedir (Demirel ve Budak, 2003).

Eğitim teknolojileri; öğrenme sürecinin planlanması, uygulanması ve değerlendirilmesi işidir (Alkan 2005, s.13). Farklı bir deyişle eğitim teknolojisi; öğretim sürecinin nasıl olması gerektiğini sorgulayan, uygun materyalleri, araç ve gereçleri seçmeyi amaçlayan bir bilim dalıdır (Vural 2004, s.25). Eğitim teknolojisinde kullanılan araçlar arasında basılı materyaller, resim, harita, grafik, modeller, yazı tahtaları, televizyon, projektörler, bilgisayar, internet sayılabilir. Günümüzde ise bilgisayar yazılımları, etkileşimli videolar, telekonferans, elektronik haberleşme eğitim teknolojilerinde önemli 
yer tutmaktadır (Akkoyunlu ve Tandoğan, 1998). Önceden sinıflarda kullanılan yazı tahtası, tepegözlerin yerine teknolojinin ilerlemesi ile akıllı tahtalar, bilgisayarlar, internet kullanılmaktadır.

Eğitim teknolojileri geliştikçe ve bu teknolojilerin öğrenme sürecini etkili kıldığı görüldükçe farklı araç ve gereçler kullanılmaktadır (Somyürek, Atasoy ve Özdemir, 2009). Bu nedenle öğretmenlerin teknoloji kullanımıyla ilgili becerilerini belirlemek için sahip olmaları gereken çeşitli standartlar oluşturulmuştur. Uluslararası Eğitim Teknolojileri Birliği ISTE (International Society for Technology in Education) öğretmenler için aşağıdaki teknolojik yeterlilikleri belirlemiştir (ISTE, 2012).

1. Öğretmenler öğrenmeyi kolaylaştırmak için teknolojiden yararlanır,

2. Öğrencilerin başarısını desteklemek, öğrenme ve öğretmeyi geliştirmek için liderlik yapar,

3. Öğrencilerin dijital dünyaya uyum sağlamaları için rehberlik yapar,

4. Öğretmenler uygulama geliştirmek, kaynakları ve fikirleri keşfetmek, sorunları çözmek için meslektaşları ve öğrencileri ile iş birliği yapar,

5. Öğretmen bireysel farklılıklara uygun öğrenci odaklı ortamlar tasarlar,

6. Öğretmenler; öğrencilerin ISTE standartlarına ulaşması için teknolojiyi kullanarak öğrenmeyi kolaylaştırır,

7. Öğretmenler; öğrencilerin öğrenme hedeflerine ulaşmalarını desteklemek için verileri anlar ve kullanır.

Millî Eğitim Bakanlığı tarafından 2017 yılında güncellenen Öğretmenlik Mesleği Genel Yeterlilikleri; mesleki bilgi, mesleki beceri, tutum ve değerler olarak üç yeterlik alanından oluşmaktadır. Bu alanların altında 11 yeterlik ve 65 gösterge bulunmaktadır (MEB, 2017). Öğrenme ve öğretme süreci yeterliğindeki öğretmen göstergelerinden biri de öğrenme ve öğretme sürecinde bilgi ve iletişim teknolojilerini etkin olarak kullanır şeklinde belirlenmiştir (MEB, 2017).

Geçmişten günümüze öğretmenlerin bilgi teknolojileri kullanımının eğitimde yeterli olup olmadığı üzerine yapılan araştırmaların incelenmesi sonucunda aşağıdaki şekilde sorunlar saptanmıştır:

- Taş, Özel ve Demirci (2007)'nin yaptığı araştırma sonucunda öğretmenlerin derslerinde teknolojik araçların kullanılmasını önemsedikleri fakat ileri seviyede grafik tasarlama, simülasyon hazırlama gibi bilgisayara yönelik teknolojileri kullanamadıkları bilgilerine ulaşılmıştır. $\mathrm{Bu}$ araştırmaya ait anket katılımcı öğretmenlere e-posta yoluyla iletilmiş ve 
bu anketi öğretmenlerin sadece yüzde beşi aynı yolla ankete cevap verebilmiştir. Bu da katılımcı öğretmenlerin internet ve bilgisayar kullanma becerilerinin hala yetersiz olduğunu göstermiştir.

- Teknoloji alanındaki gelişmeler ve değişimler eğitime de yansımıştır ve bu bağlamda her öğretmen adayının ve görevini sürdüren öğretmenin gelişen teknolojiye ayak uydurabilmesi ve mesleki gelişimlerine önem vermelidir. Öğretmenlerin hizmet öncesi eğitimlerinin yetersizliğinden dolayı, öğretmenlerin hizmet içi eğitimlerinin olması gerekmektedir. Teknoloji çağının gerektirdiği özelliklere sahip, donanımlı bireyler yetiştirilmesi için bu hizmet içi eğitimlerin sürekliliği gereklidir (Arıbaş, Kartal ve Çağlar, 2012).

- Cüre ve Özdener (2008) yaptıkları çalışma sonucunda öğretmenlerin bilgi ve iletişim teknolojilerini (BİT) kullanımının yetersiz olduğunu belirtmişlerdir. Öğretmenlerin çoğunun Word programı hakkında yeterli bilgiye sahip olmadıkları; hatta sayfa kenar boşlukları ayarlarını yapamadıkları, sayfa numarası ekleyemedikleri görülmüştür. Ayrıca öğretmenlerin büyük bir yüzdeliğinin projeksiyon ve tarayıcı gibi teknolojik aletleri kullanamadıkları ortaya konmuştur.

- Kara (2011) ise araştırmasında öğretmenlerin genel olarak sunum programlarına ve sunum slaytlarına hâkim olduğunu fakat animasyon, film gibi özelliklerde eksiklikleri olduğunu bulmuşlardır. Genel olarak ise öğretmenlerin sunum programlarını kullanma yetisi yeterli düzeydedir. İnternet kullanma becerisine bakıldığında öğretmenlerin yeteri düzeyde oldukları gözlemlenmiştir. Öğretmenler rahatlıkla internetten bilgi arayıp, dosyaları indirip kaydedebilmişlerdir.

Türkiye de diğer ülkeler gibi, eğitimde teknoloji çağına ayak uydurmak ve teknolojiyi eğitimin bir parçası haline getirmek için adımlar atmaktadır. Atılan adımların en önemlileri Fatih Projesi ve EBA eğitim platformudur. Fatih Projesi akıllı tahtalar her ne kadar tüm Türkiye'ye ulaşamasa da bu proje ile sınıf içinde teknoloji kullanımı ile eğitimde verimliliğin arttırılması amaçlanmıştır (Dursun, Kırbaş ve Yüksel, 2015). EBA eğitim platformu ile de okul dışında da öğrencinin bilgiye ulaşım sağlaması ve eğitimin sürekli hale gelmesi planlanmıştır fakat yine de birçok öğretmen geleneksel öğretim yöntemlerine devam etmiş, teknoloji kullanımını arka plana atmıştır (Aktay ve Keskin, 2016). Covid-19 pandemisinin Türkiye'de görülmesi üze- 
rine, Millî Eğitim Bakanlığı'nın kararı ile yüz yüze eğitim sona ermiş ve teknoloji tabanlı öğretim öğretmenler için mecburi hale gelmiştir. Birçok öğretmen ilk kez bu sistem ile tanışmış ve teknoloji kullanımında bazı sorunlar ile karşı karşıya gelmiştir.

$\mathrm{Bu}$ araştırmanın amacl, günümüze kadar zorunluluk haline gelmeyen eğitimde teknoloji kullanımının, Covid-19 salgını sonrasında zorunluluk haline gelmesiyle öğretmenlerin yaşadığı sorunlar, teknolojik yeterlilikleri, teknolojiyi kullanma becerileri ve hazır bulunuşluklarının ne düzeyde olduğunu ortaya koymak ve değerlendirmeler sonucunda önerilerde bulunmaktır.

Araştırmanın problemi Covid-19 pandemisi ile zorunlu hale gelen uzaktan eğitim sürecinde öğretmenlerin teknoloji kullanım yeterlilikleri hakkındaki görüşlerinin belirlenmesidir. Araştırmanın alt problemleri şu şekilde siralanabilir:

- Öğretmenlerin internet ve bilgisayar kullanımı alanındaki becerileri hakkındaki düşünceleri nelerdir?

- Uzaktan eğitim sürecinde, öğretmenlerin EBA ve diğer eğitim platformlarını kullanma becerileri hakkındaki düşünceleri nelerdir?

- Öğretmenlerin canlı derslerde görsel, işitsel materyaller ve sunum hazırlama becerileri hakkındaki düşünceleri nelerdir?

- Öğretmenlerin uzaktan eğitim araçlarına ve teknoloji kullanımına yönelik hizmet içi eğitim almalarının gerekliliği ve faydası nedir?

- Öğretmenlerin uzaktan eğitim süresince karşılaştıkları temel sorunlar nelerdir?

Teknoloji-Eğitim ve Teknoloji-Öğretmen konuları ile ilgili kapsamlı bir literatür oluşmuştur. Öğretmenlerin ve öğretmen adaylarının teknolojik yeterlilikleri, bilgisayar okur yazarlılıkları, eğitimde teknoloji kullanımları gibi konuların farklı yönlerden ele alındığı çok sayıda araştırma bulunmaktadır. Bu çalışma, öğretmenlerin teknolojik yeterlilikleri konusunda gelişmekte olan literatüre katkı sağlaması ve pandemi nedeni ile teknoloji kullanımını her bir öğretmene mecbur kılan uzaktan eğitim sürecinde öğretmenlerin hazır bulunuşluklarını, teknolojik yeterliliklerin ve karşılaştıkları sorunları ele alan ilk çalışma olması bakımından önemlidir. Aynı zamanda; öğretmenlerin teknoloji yeterliliklerinin mevcut durumunu ortaya koymak ve eğitim-öğretim sürecinde teknolojinin yerini hatırlamak açısından önem taşımaktadır. 


\section{Yöntem}

Bu bölümde araştırmanın deseni, katılımcılar, araştırmanın geçerliği ve güvenirliği, veri toplama arac1, veri toplama süreci ve veri toplama analizinden bahsedilecektir.

\section{Araştırma Deseni}

$\mathrm{Bu}$ araştırmada, uzaktan eğitim süresince öğretmenlerin teknolojik yeterlilikleri hakkında çeşitli branştaki öğretmenlerin görüşlerinin alınmıştır. Öğretmenlerin sayısı pandemiden nedeniyle erişim problemlerinden dolayı s1nırlı tutulmuştur. Araştırmada veriler, uzaktan eğitimde öğretmenlerin teknoloji yeterliliği ve karşılaştıkları sorunları hakkında farklı branşlara sahip yirmi öğretmenin görüşleri üzerinden derinlemesine anlamaya çalışıldığından dolayı olgubilim (fenomenoloji) çalışmasıdır. Olgubilim çalışmalarında bir olgu hakkında çalışmaya katılanların deneyimleri üzerinden olgular hakkında bilgi sahibi olunur (Creswell, 2007).

\section{Katılımcilar}

Araştırma, 2020-2021 eğitim-öğretim yılında iki farklı ilde ilkokul, ortaokul ve lisede görev yapan farklı branşlardaki yirmi öğretmenle yürütülmüştür. Katılımcılar, amaçlı örnekleme yöntemlerinden maksimum çeşitlilik örneklemesine göre seçilmiştir. Maksimum çeşitlilik örneklemesi; oluşturulan örneklemde çalışılan problem durumuna farklı taraf olabilecek kişilerin seçilerek çeşitliliği maksimum düzeyde göstermeyi amaçlamaktadır. Bu çeşitlilik çalışılan problemin farklı boyutlarını görmeyi sağlamaktadır (Yıldırım \& Şimşek, 2003). Araştırmanın katılımcılarına ait demografik bilgiler Tablo 1 'de sunulmuştur.

Tablo 1. Katılımcilara ait demografik bilgiler

\begin{tabular}{llll}
\hline Katılımcllar & Cinsiyet & Görev Süreleri & Katılımcıların Branşı \\
\hline Ö1 & Kadın & $1-10$ yıl & Psikolojik Danışmanlık ve Rehberlik Öğretmeni \\
\hline Ö2 & Kadın & $1-10$ yıl & İngilizce Öğretmeni \\
\hline Ö3 & Kadın & $1-10$ yıl & Bilişim Teknolojileri Öğretmeni \\
\hline Ö4 & Kadın & $11-20$ yıl & Türkçe Öğretmeni \\
\hline Ö5 & Kadın & $1-10$ yıl & İngilizce Öğretmeni \\
\hline Ö6 & Kadın & $1-10$ yıl & Fen Bilimleri Öğretmeni \\
\hline
\end{tabular}




\begin{tabular}{llll}
\hline Ö7 & Kadın & $1-10$ yll & İngilizce Öğretmeni \\
\hline Ö8 & Erkek & $1-10$ yll & İngilizce Öğretmeni \\
\hline Ö9 & Erkek & $1-10$ yl & İngilizce Öğretmeni \\
\hline Ö10 & Kadın & $1-10$ yll & İngilizce Öğretmeni \\
\hline Ö11 & Kadın & $21-25$ yll & Sinıf Öğretmeni \\
\hline Ö12 & Kadın & $21-25$ yll & Sinıf Öğretmeni \\
\hline Ö13 & Erkek & $21-25$ yll & Sinff Öğretmeni \\
\hline Ö14 & Kadın & $11-20$ yll & Sinıf Öğretmeni \\
\hline Ö15 & Erkek & $11-20$ yll & Sinıf Öğretmeni \\
\hline Ö16 & Kadın & $1-10$ yll & Görsel Sanatlar Öğretmeni \\
\hline Ö17 & Kadın & $1-10$ yll & Fen Bilimleri Öğretmeni \\
\hline Ö18 & Kadın & $1-10$ yll & Sinff Öğretmeni \\
\hline Ö19 & Kadın & $1-10$ yll & Görsel Sanatlar Öğretmeni \\
\hline Ö20 & Kadın & $1-10$ yll & Görsel Sanatlar Öğretmeni \\
\hline
\end{tabular}

\section{Veri Toplama Araci}

Araştırmada veri toplama aracı olarak araştırmacılar tarafından hazırlanan yarı yapılandırılmış görüşme formu kullanılmıştır. Görüşme yöntemi belirli bir konu hakkında derinlemesine soru sorarak, cevap yeterli bulunmadığında veya açıkça belirtilmediğinde yeniden sorarak konuyu daha net hale getirdiğinden araştırmacılar tarafından avantajlı bulunan bir yöntemdir (Çepni, 2009). Ayrıca yarı yapılandırılmış görüşmeler testlerdeki ve anketlerdeki sınırlılığı ortadan kaldırmış ve araştırmacılara esneklik sağlamıştır (Yıldırım ve Şimşek, 2003). Bu araştırmada, araştırmacılar tarafından sekiz soru belirtilmiş olup soruların kapsam geçerliliğinin sağlanması için bu sorular alan uzmanına sunularak alınan dönütlerle gerekli düzeltmeler yapılmıştır. Yarı yapılandırılmış görüşme formunun sorularının düzeltilmiş hali tekrar üç alan uzmanına incelettirilmiştir. Uzman görüşlerinden elde edilen dönütler sonrasında görüşme soruları son halini almış ve uygulamaya uygun hale getirilmiştir. Araştırmaya gönüllülük esasına göre katılan öğretmenlerin kişisel bilgilerini elde edebilmek amacıyla demografik sorular sorulmuştur.

\section{Veri Toplama Süreci}

Araştırmada nitel verileri toplamak amacıyla; görüşme formu farklı branştaki ilkokul, ortaokul ve lisede 2020-2021 eğitim-öğretim yılı güz döneminde görev yapan yirmi öğretmene uygun oldukları bir zaman diliminde 
uygulanmıştır. Görüşmeden önce öğretmenlere görüşme formu ve soruların yanıtlanmasında dikkat edilecek hususlar hakkında bilgi verilmiştir. Öğretmenler ile görüşmeler Covid-19 pandemisi nedeniyle Zoom program1 üzerinden veya yüz yüze olarak, görüşme saati belirlenerek araştırmacı tarafından yapılmıştır. Görüşme soruları öğretmenlerin bazı demografik soruları ile başlamış daha sonra sekiz maddelik görüşme sorularına geçilmiştir. Görüşme formu, her bir öğretmen ile yaklaşık yirmi dakika sürmüştür. Yapılan görüşmeler kayıt altına alınmıştır.

\section{Verilerin Analizi}

Görüşmeler sonucunda elde edilen veriler içerik analizi yapılmıştır. İçerik analizindeki amaç; elde edilen verilerin düzenlenmesi ve daha sonra sinıflandırılıp karşılaştırılması ve verilerden teorik sonuçların elde edilmesidir (Stemler, 2000). 2020 yılının mart ayında Türkiye'de görülen Covid-19 pandemisi nedeniyle bu çalışma için araştırmacılar tarafından hazırlanan görüşme soruları öğretmenlerin bir kısmıyla yüz yüze görüşülebilmiş, bir kısmı ile ise online ortamda görüşme yapılabilmiştir. Görüşme yapılırken katılımcılar tarafından tam olarak anlaşılamayan kısımlar araştırmacılar tarafından açıklanmıştır. Ses kaydına alınan görüşmeler yazılı metne dönüştürülmüş, yeniden okunmuş ve problemine uygun bulunmayan veriler ç1karılmıştır. Araştırmacılar farklı zamanlarda elde ettikleri ham verilerin analizini yapmışlardır. Yapılan analiz sonucunda farklı tema ve kodlar bulunmuştur. Elde edilen tema ve kodlar bulgular kısmında detaylı olarak verilmiştir. Araştırmada elde edilen kodların frekans dağılımları tablolarda ayrıca belirtilmiştir. Öğretmenlerin görüşlerini belirtirken görüş sahibi öğretmenlere Ö1, Ö2, Ö3... gibi kodlar kullanılmıştır.

\section{Araştırmanın Geçerliliği ve Güvenirliği}

Nitel araştırmada geçerlilik ve güvenirlik; inandırıcılık, tutarlılık, aktarılabilirlik ve teyit edilebilirlik kavramları ile sağlanmaktadır (Denzin ve Lincoln, 1994). Araştırmacılar, nitel araştırmalar üzerine yeterliliğini arttırmak, araştırmayı sürdürürken doğru bir yol izlemek ve araştırmanın güvenirliğini arttırmak amacıyla yaptıkları araştırma öncesinde nitel araştırma yöntemleri konusunda eğitim almışlardır. Çalışmanın inandırıcılı̆̆ını sağlamak 
amacıyla eğitim alanında üç uzman görüşüne başvurulmuştur. Sorulara yönelik araştırmanın amacına uygun olup olmadığına yönelik gelen geri bildirimler ile gerekli olan düzenlemeler ve düzeltmeler yapılarak, soruların geçerli ve son hali araştırma yapılmadan önce dört öğretmen ile pilot çalışma yapılmıştır. Pilot çalışma süreci sonrası araştırmanın amacına hizmet etmediği düşünülen bir soru silinmiş ve anlaşılmasında sıkıntı olan sorular düzenlenmiştir. Katılımcıların teyidi için yapılan görüşmelerden sonra kayıt altına alınan görüşmeler yazıya çevrilmiş ve katılımcılara gönderilmiştir ve okumaları istenip onayları alınmıştır. Katılımcılardan elde edilen veriler araştırmacilar tarafından analiz edilmiş ve çeşitli tema ve kodlar elde edilmiştir. Bu tema ve kodlar üç araştırmacı tarafından karşılaştırılmıştır. Analizlerin son şeklini almasında Miles ve Huberman'ın (1994) geliştirdiği formül kullanılmıştır (Güvenirlik=görüş birliği/görüş birliği+görüş ayrılığı). Araştırmacılar arasında uyum güvenirliği 0.79 olarak bulunmuştur. Kodlamacılar bir araya gelip görüş farklılıklarını kendi aralarında tartışıp kodlara son halini vermişlerdir. Bu görüşme sonrası uyum güvenirliliği 0.87 bulunmuştur. Elde edilen güvenirlik değeri yapılan bilimsel çalışmalara uygun bir değer olarak görülmektedir (Miles \& Huberman, 1994). Güvenirliği arttırmak amacıyla öğretmen görüşlerini hiç değiştirmeden, doğrudan alıntılara yer verilmiştir.

\section{Etik Kurul Raporu}

03.02.2021 tarihli ve E-61923333-050.99-11407 sayılı Sakarya Üniversitesi Sosyal ve Beşeri Bilimler Etik Kurulu Başkanlığı Uygunluk-onay belgesine göre bu araştırmanın gerçekleştirilmesinde bilim etiğine aykırı bir durum yoktur.

\section{Bulgular}

Çalışmaya katılan öğretmenlerin görüşme sorularına verdikleri cevaplar soru bazında incelenmiş ve okuyucuya sunulmuştur. Öğretmenlerin görüşmenin birinci sorusuna verdikleri yantllar doğrultusunda oluşan tema, kod ve alıntılar Tablo 2'de sunulmuştur. 
Tablo 2. Öğretmenlerin "Uzaktan eğitim süreci öncesinde derslerinize teknolojiyi entegre ediyor muydunuz? Nasıl?" sorusuna vermiş olduklarn cevaplardan oluşan tema ve kodlar

\begin{tabular}{|c|c|c|}
\hline Kodlar & Frekans-Öğretmenin Kodu & Alintı \\
\hline Akıllı tahta & (11) Ö1, 2, 3, 4, 5, 6, 7, 9, 16, 17, 19 & $\begin{array}{l}\text { Ö3 - "Akill tahtaları ve EBA'yı kullanarak } \\
\text { dersleri işliyordum." }\end{array}$ \\
\hline Bilgisayar & (7) Ö8, 11, 12, 13, 14, 15, 18 & $\begin{array}{l}\text { Ö13 - "Sinifimizda bilgisayar, projeksiyon } \\
\text { gibi teknolojik aletleri kullaniyordum." }\end{array}$ \\
\hline Video & (7) Ö2, 7, 8, 10, 12, 18, 19 & $\begin{array}{l}\text { Ö18 - "Görsel sunum, video izletip somut- } \\
\text { laşttrabiliyordum." }\end{array}$ \\
\hline Sunum & (6) Ö5, 6, 7, 8, 11, 18 & $\begin{array}{l}\text { Ö5 - "Derste ünite ile ilgili sunumlan açı- } \\
\text { yordum." }\end{array}$ \\
\hline Projeksiyon & (5) Ö8, 11, 12, 13, 15 & $\begin{array}{l}\text { Ö11 - "Derslerde daha çok bilgisayar ve pro- } \\
\text { jeksiyon aleti kullandık." }\end{array}$ \\
\hline Dinleme parçaları & (5) Ö2, 7, 8, 9, 10 & $\begin{array}{l}\text { Ö8 - "Örneğin videolar, ses kayıtları, din- } \\
\text { leme parçaların kullanıyordum." }\end{array}$ \\
\hline E-kitap & (3) Ö4, 6,10 & $\begin{array}{l}\text { Ö6- "Akill tahta uygulamalarnda e-kitap- } \\
\text { larrmız vardl." }\end{array}$ \\
\hline EBA & (2) Ö1, 3 & $\begin{array}{l}\text { Ö1 - "Uzaktan eğitim süreci öncesinde sa- } \\
\text { dece EBA'yı ve akıllı tahtayı kullanıyor- } \\
\text { dum." }\end{array}$ \\
\hline
\end{tabular}

Tablo 2 incelendiğinde, "Öğretmenlerin uzaktan eğitim öncesinde stmıflarında kullandikları teknolojik aletler" teması altında sekiz kod oluşmuştur. Bunlar; akıllı tahta, bilgisayar, video, sunum, projeksiyon, dinleme parçaları, e-kitap ve EBA'dır. Öğretmenler yüz yüze eğitimde sınıflarında imkânlar doğrultusunda akıllı tahta, bilgisayar ve projeksiyonu kullanmaktadır. Tabloya göre öğretmenlerin sunum, video kullandıkları ve e-kitap ve EBA platformunu kullananların ise az olduğu görülmektedir.

Öğretmenlerin görüşmenin ikinci sorusuna vermiş oldukları cevaplardan elde edilen tema, kod ve alıntılar Tablo 3'te sunulmuştur.

Tablo 3. Öğretmenlerin "Uzaktan eğitime başlarken teknolojiyi kullanma yeterliliği açısından ne tür zorluklarla karşılaştınız?" sorusuna vermiş oldukları cevaplardan oluşan tema ve kodlar

\begin{tabular}{|c|c|c|}
\hline Kodlar & Frekans-Öğretmenin Kodu & Alintı \\
\hline $\begin{array}{l}\text { Zoom vb uzaktan eği- } \\
\text { tim araçlarında ders ta- } \\
\text { nımlama }\end{array}$ & $\begin{array}{l}\text { (13) Ö2, 4, 5, 6, 9, 11, 12, 13, 16, } \\
17,18,19,20\end{array}$ & $\begin{array}{l}\text { Ö17 - "Ders tanımlamada zorluklar yaşa- } \\
\text { dım." }\end{array}$ \\
\hline $\begin{array}{l}\text { Uzaktan eğitim araçla- } \\
\text { rını etkin kullanma }\end{array}$ & $\begin{array}{l}\text { (12) Ö2, 4, 5, 6, 9, 11, 12, 13, 16, } \\
18,19,20\end{array}$ & $\begin{array}{l}\text { Ö5 - "Öğrenci adları nereden değişiyor, içe- } \\
\text { rik nasıl çocuklara yansittliyor onu bile bil- } \\
\text { miyordum." }\end{array}$ \\
\hline
\end{tabular}




\begin{tabular}{lll}
\hline EBA kullanma & $\begin{array}{l}(10) \text { Ö2, 6, 11, 12, 13,16, 17, 18, } \\
19,20\end{array}$ & $\begin{array}{l}\text { Ö12 - "EBA ve Zoom da yönergeleri uygu- } \\
\text { lamada sıknntılar yaşadım." }\end{array}$ \\
\hline $\begin{array}{l}\text { Kullanılan program- } \\
\text { larda alt yapı eksikliği }\end{array}$ & $(5)$ Ö5, 9, 10,16,17 & $\begin{array}{l}\text { Ö9 - "EBA'ya yüklenme olduğu için çökme } \\
\text { oluyordu ve ders yapamıyorduk." }\end{array}$ \\
\hline Zorluk yaşamama & $(5)$ Ö3, 7, 8, 14,15 & $\begin{array}{l}\text { Ö14 - "Bu konuda çok zorlukla karşılaşma- } \\
\text { dım." }\end{array}$ \\
\hline $\begin{array}{l}\text { Kullanılan programları- } \\
\text { nn dilinin İngilizce ol- } \\
\text { ması }\end{array}$ & (3) Ö4, 17,19 & $\begin{array}{l}\text { Ö19 - "Dil probleminden dolayı zorluklar } \\
\text { ile karşlaştım." }\end{array}$ \\
\hline $\begin{array}{l}\text { Office programları kul- } \\
\text { lanma }\end{array}$ & (2) Ö1,5 & $\begin{array}{l}\text { Ö1 - "Özellikle Excel konusunda eksikli- } \\
\text { ğimi fark ettim." }\end{array}$ \\
\hline
\end{tabular}

Tablo 3 incelendiğinde, öğretmenlerin ikinci soruya verdikleri cevaplar "Uzaktan eğitim sürecinde zorluk yaşama" teması altında toplanmıştır. Frekans sayılarına göre öğretmenler en fazla Zoom vb. uzaktan eğitim araçlarında ders tanımlama, uzaktan eğitim araçlarını etkin kullanma, EBA kullanmada zorluk yaşamışlardır. Bunların yanında kullanılan programlarda alt yapı eksikliği, kullanılan programlarının dilinin İngilizce olması ve Office programlarını kullanmada zorlanmışlardır. Zorluk yaşamadığını belirten beş öğretmen de bulunmaktadır. EBA platformunda yaşanan zorlukların ise alt yapı eksikliğinden kaynaklandığını, EBA'ya çok fazla giriş olmasından dolayı sitenin bunu kaldıramadığını belirtmişlerdir.

Öğretmenlerin görüşmenin üçüncü sorusuna vermiş oldukları cevaplardan elde edilen tema, kod ve alıntılar Tablo 4'te sunulmuştur.

Tablo 4. Öğretmenlerin "Uzaktan eğitim süresince teknolojik yeterlilikleriniz, bilgisayar ve internet kullanma becerileriniz hakkında ne düşünüyorsunuz?" sorusuna vermiş oldukları cevaplardan oluşan tema ve kodlar

\begin{tabular}{|c|c|c|}
\hline Kodlar & in Kodr & \\
\hline $\begin{array}{l}\text { Web sitelerini kullana- } \\
\text { bilme }\end{array}$ & $\begin{array}{l}\text { (18) Ö1, 2, 3, 4, 5, 6, 7, 8, 9, 10, } \\
11,14,15,16,17,18,19,20\end{array}$ & $\begin{array}{l}\text { Ö14- "Okulistik, eğitimhane gibi siteler- } \\
\text { den etkinlikleri indirerek kullaniyorum." }\end{array}$ \\
\hline $\begin{array}{l}\text { Uzaktan eğitim araçlarını } \\
\text { kullanabilme }\end{array}$ & $\begin{array}{l}\text { (17) Ö1, 3, 5, 6, 7, 8, 9, 10,11, 13, } \\
14,15,16,17,18,19,20\end{array}$ & $\begin{array}{l}\text { Ö11 - "Uzaktan eğitim aracı olarak EBA ve } \\
\text { Zoom programlarını kullandım." }\end{array}$ \\
\hline $\begin{array}{l}\text { Office programlarını kul- } \\
\text { lanabilme }\end{array}$ & $\begin{array}{l}\text { (16) Ö2, 3, 4, 6, 8, 9, 10, 11, 13, } \\
14,15,16,17,18,19,20\end{array}$ & $\begin{array}{l}\text { Ö14 - "Bilgisayarda Office programlarm } \\
\text { kullaniyorum." }\end{array}$ \\
\hline Sunum hazırlayabilme & $\begin{array}{l}\text { (13) Ö3, 6, 8, 9, 10,11, 13, 15, 16, } \\
17,18,19,20\end{array}$ & $\begin{array}{l}\text { Ö13 - "Bilgisayardan etkinlik, sunu hazır- } \\
\text { layabiliyordum." }\end{array}$ \\
\hline Video hazırlayabilme & $\begin{array}{l}\text { (13) Ö3, 6, 8, 9, 10, 11, 13, 15, 16, } \\
17,18,19,20\end{array}$ & $\begin{array}{l}\text { Ö6 - "Video ve sunumlarımız etkin bir şe- } \\
\text { kilde hazırladık." }\end{array}$ \\
\hline $\begin{array}{l}\text { Web } 2.0 \text { araçlarını kulla- } \\
\text { nabilme }\end{array}$ & (5) Ö6, 7, 8, 10, 14 & $\begin{array}{l}\text { Ö10 - "Web2 araçlarım daha etkin bir şe- } \\
\text { kilde kullanmaya başladım." }\end{array}$ \\
\hline
\end{tabular}


Tablo 4 incelendiğinde, öğretmenlerin üçüncü soruya verdikleri cevaplar "Bilgisayar ve internet kullanma becerileri" teması altında toplanmıştır. Öğretmenlerin sunum hazırlayabilme, Office programlarını kullanabilme, video hazırlayabilme, uzaktan eğitim araçlarını kullanabilme, web sitelerini kullanabilme, web 2.0 araçların kullanabilme şeklinde cevap verdikleri görülmektedir. Tabloya göre öğretmenlerin bilgisayardaki Office programlarını kullanabildikleri, bilgisayarda sunum ve video hazırlayabildikleri görülmektedir. Öğretmenler uzaktan eğitim aracı olarak EBA ve Zoom programlarını kullanmaktadırlar. Eğitim içerikli web sitelerinden faydalanmaktadırlar. Web 2.0 araçlarını kullanabilen çok az öğretmen olduğu görülmektedir.

Öğretmenlerin görüşmenin dördüncü sorusuna vermiş oldukları cevaplardan elde edilen tema, kod ve alıntılar Tablo $5^{\prime}$ te sunulmuştur.

Tablo 5. Öğretmenlerin "Uzaktan ĕgitim sürecinde öğretmenlere yönelik teknolojiyi kullanma yeterliliği ile ilgili bir hizmet içi eğitim verildi mi?" sorusuna vermiş olduklan cevaplardan elde edilen tema ve kodlar

\begin{tabular}{lll}
\hline \multicolumn{2}{l}{ Tema 4: Teknoloji kullanım ile ilgili eğitim } & \\
\hline Kodlar & $\begin{array}{l}\text { Frekans-Öğretmenin } \\
\text { Kodu }\end{array}$ & Alıntı \\
\hline Eğitim verilmedi & $\begin{array}{l}(12) \text { Ö1, 2, 3, 4, 5, 7, 8, 9, } \\
11,12,17,18,19,20\end{array}$ & Ö19 - "Hizmet içi eğitim verilmedi." \\
\hline $\begin{array}{l}\text { Okul tarafından yapılan bil- } \\
\text { gilendirme toplantıları }\end{array}$ & $(4)$ Ö6, 8,13,15 & $\begin{array}{l}\text { Ö15 - "Okulda bilgilendirici toplantılar } \\
\text { oldu." }\end{array}$ \\
\hline Hizmet içi & (2) Ö10, 14 & $\begin{array}{l}\text { Ö10 - "Bakanlı̆̆ın EBA üzerinden açmı̧ ol- } \\
\text { duğu kurslar ve seminerler vardı." }\end{array}$ \\
\hline $\begin{array}{l}\text { Bilişim öğretmenlerinden alı- } \\
\text { nan destek }\end{array}$ & (2) Ö10, 11,16 & $\begin{array}{l}\text { Ö16 - "Bilişim öğretmenlerinden destek al- } \\
\text { dık." }\end{array}$ \\
\hline
\end{tabular}

Tablo 5 incelendiğinde, öğretmenler "Teknoloji kullanımı ile ilgili eğitim" teması altında; eğitim verilmedi, hizmet içi eğitim, okul tarafından yapılan bilgilendirme toplantıları, bilişim öğretmenlerinden alınan destek şeklinde kodlar oluşmuştur. Öğretmenler EBA ve uzaktan eğitim araçlarıyla ilgili okul tarafından bilgilendirici toplantılar ve videolardan faydalandıklarını belirtmişlerdir. Bu konuyla ilgili hizmet içi eğitim alan öğretmenlerin az olduğu ve hizmet içi eğitim alanların EBA üzerinden kursa katıldıkları görülmektedir.

Öğretmenlerin görüşmenin beşinci sorusuna verdikleri cevaplardan elde edilen tema, kod ve alıntılar Tablo 6'da sunulmuştur. 
Tablo 6. Öğretmenlerin "Sizce öğretmenlerin teknolojiyi ĕgitime entegre etme alanında hizmet içi eğitim alması şart mıdır? Faydası olur mu?" sorusuna verdikleri cevaplardan elde edilen tema ve kodlar

Tema 5: Hizmet içi eğitimin gerekliliği

\begin{tabular}{|c|c|c|}
\hline Kodlar & $\begin{array}{l}\text { Frekans-Öğretmenin } \\
\text { Kodu }\end{array}$ & Alıntilar \\
\hline Zorunlu olmalıdır & $\begin{array}{l}\text { (13) Ö1, 2, 4, 5, 7, 8, 10, } \\
11,12,13,16,19,20\end{array}$ & $\begin{array}{l}\text { Ö8 - "Hizmet içi eğitimin kesinlikle yapılması la- } \\
\text { zlm." }\end{array}$ \\
\hline Faydası olur & (7) Ö3, 6, 9, 14, 15, 17, 18 & $\begin{array}{l}\text { Ö3 - "Dersler bu eğitimler sayesinde daha akıc işle- } \\
\text { nir ve öğrencilere faydası olur." }\end{array}$ \\
\hline \multicolumn{3}{|c|}{ Tema 6: Hizmet içi eğitimin faydaları } \\
\hline Kodlar & $\begin{array}{l}\text { Frekans-Öğretmenin } \\
\text { Kodu }\end{array}$ & Alıntılar \\
\hline $\begin{array}{l}\text { Dersin anlaşlılılığı ve ve- } \\
\text { rimliliği arttırma }\end{array}$ & $\begin{array}{l}\text { (13) Ö2, 3, 4, 7, 9, 12, 13, } \\
14,15,16,17,19,20\end{array}$ & $\begin{array}{l}\text { Ö4 - "Öğretmene bu eğitimler verilseydi dersler } \\
\text { daha verimli geçerdi." }\end{array}$ \\
\hline $\begin{array}{l}\text { Zoom vb. araçları kulla- } \\
\text { nabilme }\end{array}$ & (6) Ö2, 5, 6, 8, 17, 20 & $\begin{array}{l}\text { Ö17 - "Ders esnasindaki programı kullanma yetim } \\
\text { daha iyi olurdu." }\end{array}$ \\
\hline $\begin{array}{l}\text { EBA kullanımında ko- } \\
\text { laylık }\end{array}$ & (4) Ö10, 11, 17, 20 & $\begin{array}{l}\text { Ö10 - "EBA'nın bu kadar farklı alanlara hizmet ede- } \\
\text { ceğini ve zengin içeriğe sahip olduğunu bilmiyor- } \\
\text { dum." }\end{array}$ \\
\hline Materyal hazırlama & (4) Ö1, 13, 16, 17 & $\begin{array}{l}\text { Ö1 - "Hizmet içi eğitim olsaydl çocuklara görsel ola- } \\
\text { rak daha iyi materyaller sunulurdu." }\end{array}$ \\
\hline $\begin{array}{l}\text { Bilgisayar kullanımında } \\
\text { kolaylık }\end{array}$ & (3) $\mathrm{Ö} 8,11,18$ & $\begin{array}{l}\text { Ö11 - "Bilgisayara hâkim olamadıktan sonra EBA } \\
\text { gibi platformlar da kullanamıyorsun." }\end{array}$ \\
\hline Çevrim içi sınıf yönetimi & (2) Ö6, 7 & $\begin{array}{l}\text { Ö6 - "Eğlence anlayışı farklı kişiler sunumumuza } \\
\text { girerek küfür, hakaret, nefret içerikli paylaşımlar ger- } \\
\text { çekleştiriyorlar." }\end{array}$ \\
\hline
\end{tabular}

Tablo 6 incelendiğinde, öğretmenlerin "Hizmet içi eğitimin gerekliliği" teması altında verdiği yanıtlar "faydası olur" ve "zorunlu olmalıdır" şeklindedir. Öğretmenlerden bazıları hizmet içi eğitimin zorunluluğu üzerinde durmamış, alınırsa faydalı olacağını belirtmiştir. Öğretmenlerden on üç tanesi hizmet içi eğitimin öğretmenler için zorunlu olması gerektiğini, yedi tanesi ise faydalı olacağını belirtmiştir.

Öğretmenlerin verdiği cevaplara göre "Hizmet içi eğitimin faydaları" teması altında; dersin anlaşılırlığı ve verimliliği arttırma, Zoom vb. araçları kullanabilme, EBA kullanımında kolaylık, materyal hazırlama, bilgisayar kullanımında kolaylık, çevrimiçi sınıf yönetimi kodları oluşmuştur. Öğretmenlerin çoğu hizmet içi eğitimin faydalı olacağını düşünmektedirler. Özellikle uzaktan eğitim araçlarını daha etkin kullanabileceklerini ve derslerin verimliliğini arttıracağını düşünmektedirler. Bilgisayar becerilerine 
sahip olmadan bu araçları kullanmada zorluk yaşayacaklarını ve bilgisayarla ilgili hizmet içi eğitim alınmasının faydalı olacağını belirtmişlerdir. Ayrıca uzaktan eğitimde yaşanan istenmeyen olayları önlemek açısından eğitimin faydalı olacağını da belirtmişlerdir.

Öğretmenlerin görüşmenin altıncı sorusuna verdikleri cevaplardan elde edilen tema, kod ve alıntılar Tablo 7'de sunulmuştur.

Tablo 7. Öğretmenlerin "Yeteri kullanım becerisine sahip olmadan EBA veya diğer uzaktan eğitim platformlan üzerinden işlenen derslerde konular net, açık ve anlaşılır şekilde işlenebildi mi?" sorusuna verdikleri cevaplardan elde edilen tema ve kodlar

\begin{tabular}{|c|c|c|}
\hline Kodlar & $\begin{array}{l}\text { Frekans-Öğretmenin } \\
\text { Kodu }\end{array}$ & Alintilar \\
\hline Dersler açık ve netti & $\begin{array}{l}\text { (13) Ö1, 3, 6, 7, 9, 10, 12, } \\
14,15,16,17,19,20\end{array}$ & $\begin{array}{l}\text { Ö3 - "Kendi açımdan açı ve net işleyebildim ders- } \\
\text { lerimi." }\end{array}$ \\
\hline Dersler anlaşılırd 1 & $\begin{array}{l}\text { (13) Ö1, 3, 4, 6, 7, 9, 10, } \\
11,12,14,15,16,17\end{array}$ & $\begin{array}{l}\text { Ö12 - "Derse katılan öğrenciler dersi anliyor ve bir } \\
\text { sıkıntı yaşamıyorlar." }\end{array}$ \\
\hline Dersler verimliydi & (5) Ö2, 7, 10, 12, 15 & $\begin{array}{l}\text { Ö10 - "Bazı kademelerde uzaktan eğitimde dersle- } \\
\text { rimin daha verimli geçtiğini fark ettim." }\end{array}$ \\
\hline $\begin{array}{l}\text { Dersler açık, net, anlaşılır } \\
\text { ve verimli değildi }\end{array}$ & (4) Ö5, 8, 13, 18 & $\begin{array}{l}\text { Ö5 - "Konuların net ve anlaşılı biçimde işlenebile- } \\
\text { ceğini ve yüz yüze eğitim gibi verimli olacağın dü- } \\
\text { şünmüyorum." }\end{array}$ \\
\hline
\end{tabular}

Tablo 7 incelendiğinde, "Uzaktan eğitimde işlenen derslerin durumu" teması altında, öğretmen görüşleri sonucunda; dersler açık ve netti, dersler anlaşılırdı, dersler verimliydi ve dersler açık, net, anlaşılır ve verimli değildi şeklinde dört kod oluşturulmuştur. Öğretmenlerin çoğu dersi açık ve net bir şekilde işleyebildiklerini fakat bunun hiç bir şekilde yüz yüze eğitimin yerini tutmadığını belirtmişlerdir. Bununla ilgili Ö17, "Dersim Fen Bilgisi olduğu için çocuklara somut kavramlarn ifade edebilmek adına görsellerle, sunu ve videolarla dersimi açık ve net şekilde işlemeye çalıştım. Ama yüz yüze eğitimdeki kadar anlaşılır olduğunu düşünmüyorum." şeklinde ifadede bulunmuştur. Öğretmenlerden beş tanesi derslerin verimli geçtiğini belirtirken dört tanesi de verimsiz geçtiğini belirtmiştir.

Öğretmenlerin görüşmenin yedinci sorusuna verdikleri cevaplardan elde edilen tema, kod ve alıntılar Tablo 8'de sunulmuştur. 
Tablo 8. Öğretmenlerin "İşlediğiniz derslerde dersi aktif kılabilmek için sunum ve görsel materyalleri hazırlarken zorluk yaşadını mı?" sorusuna verdikleri cevaplardan elde edilen tema ve kodlar

\begin{tabular}{|c|c|c|}
\hline \multicolumn{3}{|c|}{ Tema 8: Uzaktan eğitimde görsel materyal ve sunum hazırlama durumu } \\
\hline Kodlar & $\begin{array}{l}\text { Frekans-Öğretmenin } \\
\text { Kodu }\end{array}$ & Alıntılar \\
\hline $\begin{array}{l}\text { Hazır sunum kul- } \\
\text { lanma }\end{array}$ & $\begin{array}{l}\text { (13) Ö1, 2, 4, 5, 6, 7, 9, 10, } \\
13,14,16,17,18\end{array}$ & Ö18 - "Hazır sunum kullanıyorum." \\
\hline $\begin{array}{l}\text { Basit düzeyde sunum } \\
\text { hazırlama }\end{array}$ & $\begin{array}{l}\text { (11) Ö4, 6, 8, 9, 10, 11, 12, } \\
15,16,19,20\end{array}$ & $\begin{array}{l}\text { Ö4 - "Sadece power point ile basit düzeyde sunum ha- } \\
\text { zirlayabilirdim." }\end{array}$ \\
\hline $\begin{array}{l}\text { Görsel materyal ha- } \\
\text { zurlama }\end{array}$ & $\begin{array}{l}\text { (10) Ö3, 8, 9, 10, 11, 12, } \\
15,16,19,20\end{array}$ & $\begin{array}{l}\text { Ö16- "İ̧lediğim derse uygun görsel materyalleri inter- } \\
\text { nette bulamadığım zaman kendim hazırlayp ekrana } \\
\text { yansittım." }\end{array}$ \\
\hline $\begin{array}{l}\text { İyi düzeyde sunum } \\
\text { hazırlama }\end{array}$ & (6) Ö3, 8, 9, 10, 15, 17 & Ö3 - "Kendim kolaylkkla sunum hazırlayabiliyorum." \\
\hline
\end{tabular}

Tablo 8 incelendiğinde, uzaktan eğitimde "Görsel materyal ve sunum hazırlama durumu" teması altında; hazır sunum kullanma, basit düzeyde sunum hazırlama, iyi düzeyde sunum hazırlama, görsel materyal hazırlama kodları oluşturulmuştur. Öğretmenlerin çoğu uzaktan eğitim sürecindeki derslerinde hazır sunum kullanmıştır. Ö2, "Şu an sunum hazırlayamadı̆̆ım için hazır sunum kullanıyorum." şeklinde, Ö5 ise "Hazır sunum kullanıyorum. Hazır olmasa çok büyük sorun yaşardım. Kullandığım sunularda her türlü etkinlik var. Ben hazırlayamazdım." şeklinde görüş belirtmiştir. Öğretmenler arasında çoğunluk basit düzeyde olmak üzere iyi düzeyde sunum hazırlayabilenler de vardır. Görüşme yapılan yirmi öğretmenin yarısı görsel materyaller hazırlayabildiğini belirtmiştir. Ö11, "Daha çok kartonla, ev araç gereçleriyle görsel materyaller hazırlıyorum. Matematikte sayma çubukları olarak çöp şişleri kullanıyorum, fasulye, nohut kullanıyorum. Kartondan görseller hazırlıyorum, çıtı alıp keserek kuklalar hazırlıyorum. Bilgisayardan bulup kopyala yapıştır ile örneğin horoz resmini alıp yanına 'üüü̈' yazarak materyal hazırladım." şeklinde görüşlerini belirmiştir.

Öğretmenlerin görüşmenin sekizinci sorusuna verdikleri cevaplardan elde edilen tema, kod ve alıntılar Tablo 9'de sunulmuştur. 
Tablo 9. Öğretmenlerin "Öğretmenlerin uzaktan eğitim süresince karşılaştıkları temel sorunlar nelerdir, nasıl düzeltilmelidir?" sorusuna verdikleri cevaplardan elde edilen tema ve kodlar

\begin{tabular}{|c|c|c|}
\hline \multicolumn{3}{|c|}{ Tema 9: Uzaktan eğitim sürecinde karşılaşılan sorunlar } \\
\hline Kodlar & Frekans-Öğretmen kodu & Alintilar \\
\hline Teknolojik cihaz eksikliği & $\begin{array}{l}\text { (15) Ö6, 7, 8, 9, 10, 11, 12, 13, } \\
14,15,16,17,18,19,20\end{array}$ & $\begin{array}{l}\text { Ö6 - "Evlerinde tablet veya bilgisayarn ol- } \\
\text { mamast bu süreci biraz daha zorlaştrdrd." }\end{array}$ \\
\hline İnternet sıkıntısı & $\begin{array}{l}\text { (15) Ö1, 2, 4, 5, 6, 7, 8, 9, 11, } \\
12,13,14,15,16,17\end{array}$ & $\begin{array}{l}\text { Ö13 - "Tablet ulasstrirlan o evde internet } \\
\text { yoksa bir faydast olamayacak." }\end{array}$ \\
\hline Öğrenci katılımı eksikliği & $\begin{array}{l}\text { (9) Ö1, 5, 6, 7, 10, 12, 13, 15, } \\
17\end{array}$ & $\begin{array}{l}\text { Ö7 - "Derslere hiç gelemeyen ö̆renciler var } \\
\text { ve biz bu ögrencilere aylardır ulaşamıyoruz." }\end{array}$ \\
\hline $\begin{array}{l}\text { Teknolojik eğitim yeter- } \\
\text { sizliği }\end{array}$ & (7) Ö1, 2, 3, 4, 8, 9, 19 & $\begin{array}{l}\text { Ö1 - "Öğretmenlerin teknolojik açıdan yeter- } \\
\text { siz olması da sorun." }\end{array}$ \\
\hline $\begin{array}{l}\text { Öğrencilerin ders moti- } \\
\text { vasyonu düşüklüğüu }\end{array}$ & (3) Ö7, 8,10 & $\begin{array}{l}\text { Ö7 - "Öğrencileri motive etmek sıkıntı olabi- } \\
\text { liyor." }\end{array}$ \\
\hline
\end{tabular}

Tablo 9 incelendiğinde, “Öğretmenlerin uzaktan eğitim sürecinde karşılaşılan sorunlar" teması altında en büyük iki sorunun; teknolojik cihaz eksikliği ve internet sıkıntısı olduğu buna bağlı olarak da öğrenci katılımı eksikliği görülmüştür. Ayrıca teknolojik eğitim yetersizliği ve öğrencilerin ders motivasyonu düşüklüğü gibi sorunların da yaşandığı görülmüştür. Ö̆ğretmenlerin çoğu temel sorun olarak teknolojik cihaz eksikliği ve internet eksikliği gibi maddi sıkıntıları görmektedir. Öğrenciler bilgisayar ve tablet eksikliğinden ya da evlerinde internet olmayışından derslere katılamamaktadırlar. Maddi sıkıntılar ya da aile ilgisizliği nedeniyle de öğrencilerin bir kısmının derslere katılamadığını ve bunun sorun olduğunu belirtmişlerdir. Ayrıca derslerin uzaktan olmasının bazı öğrencilerde motivasyon eksikliği oluşturarak sıkıntı yarattığını belirtmişlerdir.

\section{Tartışma ve Sonuç}

Uzaktan eğitim sürecinde öğretmenlerin teknolojik yeterliliklerinin araştırıldığı bu çalışmanın bulguları alan yazın ışığında tartışılarak sunulmuştur.

Uzaktan eğitim süreci öncesinde öğretmenlerin bilgisayar, akıllı tahta, projeksiyon ile EBA, sunum, vb. araçlarla teknolojiyi derslerine entegre ettikleri gözlenmiştir (Tablo 2). Bu konuda Kuzgun ve Özdinç (2017) yapmış olduğu çalışmada eğitimde teknoloji kullanımında çoğunlukla kullanılan teknolojilerin bilgisayar, internet ve projeksiyon gibi geleneksel araçlar olduğunu belirtmiştir. Burada elde edilen veriler öğretmenlerin imkânları ve 
okulun bulunduğu imkân ve koşulları dahilinde derslerine projeksiyon, bilgisayar, internet, akıllı tahta gibi teknolojiyi dahil ederek derslerinde verimliliği ve çeşitliliği sağladıkları gözlenmiştir.

Öğretmenler uzaktan eğitim sürecine başlarken teknolojiyi kullanma açısından bazı zorluklar yaşamışlardır. Öğretmenler bu zorlukları; EBA ve Zoom gibi uzaktan eğitim araçlarını kullanmada yaşanılan zorluklar, kullanılan programlardaki altyapı eksikliği nedeniyle yaşanılan zorluklar, bilgisayar programlarını kullanmada yaşanılan zorluklar olarak belirtmişlerdir. Ayrıca bazı uzaktan eğitim araçlarının kullanım dilinin İngilizce olması nedeniyle zorluk yaşadıklarını da belirtmişlerdir (Tablo 3). Tutar (2015) yaptığı çalışmasında öğretmenlerin EBA platformunu kullanma oranlarını \%44.8 olarak belirtmiştir. Öğretmenler uzaktan eğitime geçildiğinde EBA platformunu canlı dersler yapmak amaciyla da kullanmaya başlamış ve uzaktan eğitim öncesine göre yoğun bir kullanım gerçekleşmiştir. Bu da EBA platformunun alt yapısı ile ilgili sorunları gündeme getirmiştir. Doğan ve Koçak (2020), yaptıkları çalışmada uzaktan eğitimde öğretmenlerin EBA platformunun alt yapı eksikliğinden kaynaklanan sorunlar yaşadığını belirtmiştir.

Öğretmenlere uzaktan eğitim sürecindeki teknoloji kullanım yeterlilikleri sorulmuştur ve uzaktan eğitim araçlarını, bilgisayarda Office programların kullanabildiklerini, sunum ve video hazırlayabildiklerini belirlenmiştir (Tablo 4). Web 2.0 araçlarını kullanabilen öğretmen sayısı ise az olduğu görülmektedir. Öğretmenler uzaktan eğitim araçları olan EBA ve Zoom programlarını sürecin başında zorluk yaşasalar da kullanabilmektedirler. Programlarda ders tanımlama, dersi başlatma ve içerik paylaşma yapabilmektedirler. Korucu ve Karalar (2017)'in yaptı̆̆ araştırma sonucuna göre öğretim elemanları Web 2.0 araçlarının derslerde aktif olarak kullanılmasının öğrencinin öğrenimine katkısının olacağına inanmaktadırlar fakat öğretim elemanları Web 2.0 araçlarını derslerinde yeteri kadar kullanmamakta ve gelecekte de kullanmak istememektedirler.

Uzaktan eğitim sürecinde öğretmenlere zorunlu bir hizmet içi eğitim verilmemiştir. Öğretmenlerin bir kısmı EBA üzerindeki hizmet içi eğitim alırken birçoğu okul tarafından bilgilendirici videolar ile süreç hakkında bilgi sahibi olmuştur. Bunların dişında okuldaki bilişim öğretmenlerinden de destek almışlardır (Tablo 5). Arık (2020) yaptığı çalışmada EBA ve kullanımı ile ilgili tüm bilgilerin EBA web sitesinde bulunduğunu belirtmiştir. 
Gönen ve Kocakaya (2006)'ya göre yapılan araştırmalar sonucunda öğretmenlerin çağın yeniliklerine uygun yöntem ve tekniklerin derslerde uygulanması hakkında yeterli bilgiye sahip olmamalarına rağmen hizmet içi eğitim uygulamalarının tam anlamıyla gerçekleştirilemediği ortaya çıkmış ve hizmet içi eğitimlerin arttırılmasının gerekliliği vurgulanmıştır.

Öğretmenler teknoloji eğitimiyle ilgili hizmet içi eğitimin gerekli olduğunu ve faydaları olacağını belirtmektedirler. Hizmet içi eğitimin; bilgisayar kullanımında, EBA, Zoom, vb. programları kullanmada, çevrimiçi sınıf yönetiminin daha etkili olmasını sağlamada, çevrimiçi materyal hazırlayabilme ve dersin anlaşılırlığını, verimliliğini arttırmada faydalı olacağı düşünülmektedir (Tablo 6). Yıldırım (2020) yaptığı çalışmada öğretmenlerin teknoloji ve çevrimiçi eğitim ortamlarına yönelik becerilerini arttırmak için eğitim verilmesi gerektiği sonucuna ulaşmıştır.

Öğretmenler uzaktan eğitimde işlenen derslerin açık, net, anlaşılır ve verimli işlendiğini belirtilmiştir (Tablo 7). Geleneksel eğitim modelinin aksine uzaktan eğitimde öğretmenlerin görsel ve işitsel kaynaklar kullanarak işlenilen derslerde pek çok duyu organına hitap etmesi derslerin anlatımını daha etkin ve verimli kılmıştır. Bu şekilde çeşitli materyaller işlenilen derslerde öğrencilere daha kalıcı öğrenme sağlar ve bu tür bir öğretme modeli yüz yüze eğitime nazaran daha etkili bir öğrenme ortamı sağlar. Akyürek (2020) yaptı̆̆ çalışma sonucunda uzaktan eğitimin öğretmen ve öğrenci etkileşimi ile etkili ve faydalı olabileceğini belirtmiştir.

Öğretmenler işlediği derslerde dersi aktif kılabilmek adına sunum ve görsel materyalleri hazırlarken zorluk yaşamadıklarını, hazır sunum kullandıklarını ve sunum hazırlayabildiklerini belirtmişlerdir (Tablo 8). Öğretmenlerin derslerini daha verimli ve aktif kılabilmek adına materyal ve sunum hazırladıkları, sunumların genelde hazır sunum olduğu ve kendi hazırladıkları sunumların basit düzeyde olduğu görülmektedir. Kara (2011)'nın çalışmasına göre; öğretmenler sunum programlarına ve slayt hazırlamaya hâkimler ve sunum programlarını yeterli düzeyde kullanmaktadırlar ancak animasyon, film gibi özelliklerde eksiklikleri bulunmaktadır.

Uzaktan eğitimde yaşanan temel sorunların başında teknolojik cihaz eksikliği, internet sıkıntısı, derslere öğrenci katılımında eksiklik, teknolojik eğitim yetersizliği ve öğrencide motivasyon düşüklüğü gelmektedir (Tablo 9). Başaran, Doğan, Karaoğlu ve Şahin (2020) yaptıkları araştırmada uzak- 
tan eğitimin faydaları yanında öğrenci katılımının az olması, teknik aksaklıklar yaşanması, alt yapı ve içerik materyal eksikleri olduğunu belirtmişlerdir.

\section{Öneriler}

Uzaktan eğitim süreciyle öğretmenlerin teknolojiyi kullanmaları zorunluluk haline gelmiştir. Öğretmenler bu süreçte EBA ve Zoom gibi uzaktan eğitim araçlarını kullanmakta, derslerde kullanmak üzere sunum, video, görsel materyaller hazırlamaktadırlar. Öğretmenler bu süreçte birçok sorun yaşadıklarını da ifade etmişlerdir. Bu nedenle öğretmenlerin teknoloji kullanımına ve uzaktan eğitim araçlarını kullanmaya yönelik eğitim almaları faydalı olabilir. Bu eğitimler yalnızca bu araçları kullanmaya yönelik değil günümüz bilgi çağının gerekliliği olan 21. yüzyıl becerilerini destekleyecek şekilde etkili ve aktif kullanmayı sağlayacak nitelikte olmalıdır. Öğretmenlere Web 2.0 araçları ile ilgili eğitimler verilmeli ve bu araçları derslerinde kullanmaları teşvik edilmelidir. Uzaktan eğitim süreci halen kullanılmakta ve yaygınlaşmakta olduğu için öğrenme ortamları ile öğrenci ve öğretmen arasındaki etkileşimin kalitesi arttırılmalıdır. Bunun için öncelikle uzaktan eğitimin alt yapı eksiklikleri giderilmeli, öğrenci ve öğretmenlerin bilgisayar ve internet sorunları çözülmeli, öğretmenlerin temel teknoloji kullanımına ve uzaktan eğitim araçlarının etkin kullanımına yönelik hizmet içi eğitim verilmelidir.

Öğretmenlerle ilgili bağımsız değişkenlere (yaş, cinsiyet, okul türü, branş) göre yapılacak çalışmanın farklı sonuçlar elde edilmesi olasılığından çalışılması önerilmektedir. Ayrıca bu araştırma nitel bir araştırma olarak yürütülmüştür. Karma ya da nicel araştırmalarla daha farklı sonuçlar alınarak araştırma güçlendirilebilir. 


\title{
EXTENDED ABSTRACT
}

\section{Investigation of Teachers' Use of Technology in the Distance Education Process}

\author{
Mehmet Başaran - Irmak Gül Ülger - Merve Demirtaş \\ Elif Kara - Ceylan Geyik - Ömer Faruk Vural \\ Gaziantep University, Şehit Ümüt Özcan Primary School, İpekyolu Secondary School, Merveşehir \\ Secondary School, Sakarya University
}

This research reveals the difficulties, problems, technological competencies, technology use skills, and readiness experienced by teachers and students while integrating technology, which became mandatory after the Covid-19 epidemic. In the 2020-2021 academic year, a study was conducted with 20 teachers from different branches working in primary, secondary, and high schools. The study was prepared by collecting data with a semi-structured interview form prepared by the researchers using the qualitative research technique. Content analysis was used to analyze the data.

In the 21st century, technology is used in all areas of life and is rapidly changing. Especially the changes in information and communication technologies affect the education system as well as every field. Advances in technology necessitate changes in the education system and teachers' professional skills. Different teaching environments should be arranged for teachers and students to adapt to these innovations and access information. For this reason, technology has become an indispensable part of the learning process. To use technology effectively and be a model for students, they should know about computers and feel competent. The use of distance education has become widespread, primarily due to the Covid-19 epidemic in the world. The Covid-19 outbreak, which was seen for the first time in December 2019 in Wuhan, China, is a pandemic that adversely affected all world countries in a short time. In Turkey, the education process has been suspended temporarily, and instead, it has been decided by all countries that students will continue their distance education with technological 
tools. In this process, many teachers experienced uneasiness about conducting distance education and had some difficulties in the distance education process.

Teachers stated in detail that they had difficulties using Zoom and EBA and distance education tools at the beginning of the distance education process, and these problems were experienced. The Covid-19 outbreak has shown us that education and technology should always be intertwined; Teachers should be open and ready to always use this information technology. Teachers have difficulties using distance education tools such as EBA and Zoom, difficulties experienced due to the lack of infrastructure in the programs used, and difficulties in using computer programs. They also stated that they had difficulties because the language of some distance education tools is English.

Teachers stated that they prepared simple presentations and visual materials to be able to process the lesson more permanently and effectively, they used ready-made presentations in their lessons when necessary, and that they did not use Web 2.0 tools. It is seen that the number of teachers who can use Web 2.0 tools is low. Teachers can use EBA and Zoom programs, which are distance education tools, even if they have difficulties at the beginning of the process. In the programs, they can define, start the course, and share content. They believe that the active use of Web 2.0 tools in the lessons will contribute to the student's learning, but the instructors do not use Web 2.0 tools enough and do not want to use them in the future.

Teachers stated that the lessons taught in distance education are handled more clearly, understandably, and efficiently with the prepared presentations, videos, and visual materials. It was observed that teachers' technological competencies were lacking, and it was determined that they did not receive in-service training at school on the use of technology.

With Covid-19, developments and changes in technology have also reflected in education, and in this context, every teacher candidate and continuing teacher should keep up with the developing technology and pay attention to their professional development. While some of the teachers received in-service training on EBA, many of them were informed about the process by the school through informative videos. Apart from these, it was observed that they learned with the support of the IT teachers at the school. Teachers say that in-service training on technology education is necessary 
and will have benefits. In-service training: in computer use, EBA, Zoom, etc. It is thought that it will be beneficial in using the programs, making the online classroom management more effective, preparing online materials, and increasing the course's clarity and efficiency. Continuity of these in-service pieces of training is necessary to raise well-equipped individuals with the features required by the age of technology.

Before the distance education process, the main problems experienced in the distance education process are the lack of technological devices, since the same opportunities that teachers provide efficiency and diversity in their lessons by including technology such as projection, computer, internet, smartboard in their lessons within the opportunities and conditions of the school, are not in the distance education process. There are internet problems, lack of student participation in classes, lack of technological education, technical problems, lack of material, and students' low motivation.

Teachers also stated that they experienced many problems during this process. For this reason, it may be beneficial for teachers to receive training on using technology and using distance education tools. These pieces of training should be qualified not only to use these tools but also to ensure effective and active use in a way that supports the 21st-century skills that are the necessity of today's information age. Teachers should be trained about Web 2.0 tools, and they should be encouraged to use these tools in their lessons. Since the distance education process is still used and spreading, the quality of the learning environments and the interaction between students and teachers should be increased. First, infrastructure deficiencies of distance education should be eliminated, computer and internet problems of students and teachers should be resolved, in-service training should be provided for teachers to use essential technology and effective distance education tools.

\section{Kaynakça / References}

Akkoyunlu, B. (1995). Bilgi teknolojilerinin okullarda kullanımı ve öğretmenlerin rolü. Hacettepe Üniversitesi Eğitim Fakültesi Dergisi, 11(11), 105-109.

Akkoyunlu, B. ve Tandoğan, M. (1998). Çağdas eğitimde yeni teknolojileri. Eskişehir: Anadolu Üniversitesi Yayınları. 
Akpınar, Y. (2003). Öğretmenlerin yeni bilgi teknolojileri kullanımında yükseköğretimin etkisi: İstanbul okulları örneği. The Turkish Online Journal of Educational Technologyy, 2(2), 79-96. ISSN: 1303-6521.

Aktay, S. \& Keskin, T. (2016). Eğitim bilişim ağ (EBA) incelemesi. Eğitim Kuram ve Uygulama Araştrmalarn Dergisi, 2(3), 27-44. hettp://dergipark.org.tr/tr/en/pub/mead/issue/56310/7111904

Akyürek, M. (2020). Uzaktan eğitim: bir alan yazın taraması. Medeniyet Ĕgitim Araştırmalarn Dergisi, 4(1), 1-9. https://dergipark.org.tr/en/pub/mead/is$\underline{\text { sue } / 56310 / 711904}$

Alkan, C. (1981). Açıöğretim: Uzaktan eğitim sistemlerinin karşlaştırmalı olarak incelenmesi. Ankara: Ankara Üniversitesi Eğitim Bilimleri Fakültesi Yayınları.

Alkan, C. (2005). Eğitim teknolojisi (7. bs.). Ankara: Anı Yayıncllk.

Arrbaş, S., Kartal, Ş., ve Çağlar, İ. (2012) İngilizce öğretmenlerinin hizmet içi eğitim faaliyetlerine ilişkin görüşleri. Milli Eğitim Dergisi, 42(195), 100-117.

Arı, B. M. (2020, Mart 24). Türkiye'de koronavirüsün eğitime etkileri-II, uzaktan eğitim nasıl olacak ve bu süreçte neler dikkate alnmall?. 08.01.2021 tarihinde https://www.egitimreformugirisimi.org/turkiyede-koronavirusun-egitime-etkileri-ii-uzaktanegitim-nasil-olacak-ve-bu-surecte-neler-dikkate-alinmali/adresinden erişildi.

Başaran, M., Doğan, E., Karaoğlu, E., ve Şahin, E (2020). Koronavirüs (Covid-19) pandemi sürecinin getirisi olan uzaktan eğitimin etkililiği üzerine bir çalışma. Academia Eğitim Araştrmalar Dergisi 2020,5(2), 368-397. https://dergipark.org.tr/tr/pub/egitim/issue/54643/753149

Bozkurt, A. (2017). Türkiye'de uzaktan eğitimin dünü, bugünü ve yarını. Açıkögrretim Uygulamalar ve Araştırmalan Dergisi, 3(2), 85-124.

Creswell, J. W. (2007). Qualitative inquiry and research design: Choosing among five approaches, 2nd Ed. Thousand Oaks, CA: Sage Publishers.

Cüre, F. \& Özdener, N. (2008). Teachers' information and communication technologies (ICT) using achievements and attitudes towards ICT. Hacettepe University Journal of Education, 34, 41-53.

Çepni, S. (2009). Araştırma ve proje çalişmalarina giriş (4. bs.). Trabzon: Celepler Matbaactlik.

Demirel, Ö. ve Budak, Y. (2003). Öğretmenlerin hizmetiçi eğitim ihtiyacı. Kuram ve Uygulamada Egitim Yönetimi Dergisi, 9(1), 62-81.

Denzin, N. K. ve Lincoln, Y. S. (1994). Handbook of qualitative research. California, USA: Sage Publications.

Dinçer, Ö. G. S. (2016). Bilgisayar destekli eğitim ve uzaktan eğitime genel bir bakış. Adana, Seyhan, Türkiye. 
Doğan, S. ve Koçak, E. (2020). EBA sistemi bağlaminda uzaktan eğitim faaliyetleri üzerine bir inceleme. Ekonomi ve Sosyal Araştırmalar Dergisi, 7(14), 111-124.

Dursun, A., Kırbaş, İ., ve Yüksel, M. E. (2015). Fırsatları artırma ve teknolojiyi iyileştirme hareketi (FATIH) projesi ve proje üzerine bir değerlendirme. Türkiye'de Internet Konferansi, İstanbul Üniversitesi, İstanbul.

Ertuğ, C. (2020). Coronavirüs (Covid-19) pandemisi ve pedagojik yansımaları: Türkiye' de açık veuzaktan eğitim uygulamaları. Açıöŏgretim Uygulamaları ve Araşttrmalarn Dergisi, 6(2), 11-53.

Göktaş, Y., Yıldırım, Z., ve Yıldırım, S. (2010). Bilgi ve iletişim teknolojilerinin eğitim fakültelerindeki durumu: Dekanların görüşleri. Ĕ̆itim ve Bilim, 33(149), 30-50.

Gönen, S. \& Kocakaya, S. (2006). Fizik öğretmenlerinin hizmet içi eğitimler üzerine görüşlerinin. Pamukkale Üniversitesi Eğitim Fakültesi Dergisi, 19(19), 37-44

International Society for Technology in Education (ISTE). (2012). National educational technology standards. 14.11.2020 tarihinde http://cnets.iste.org adresinden erişildi.

Kara, S. (2011). İköğretim okullarında görev yapan öğretmenlerin bilgi ve iletişim teknolojileri yeterliliklerinin belirlenmesi, İstanbul örneği (Yayımlanmamış yüksek lisans tezi). Bahçeşehir Üniversitesi, İstanbul.

Kaya, Z. (2006). Öğretim teknolojileri ve materyal geliştirme. Ankara: Pegem A Yayıncılık.

Keleş, E. ve Güntepe, E. T. (2018). Eğitim fakültesi öğretim elemanlarının teknolojìyi öğrenme-öğretme sürecine entegrasyonu. Sakarya University Journal of Education, 8(3), 142-157.

Korucu, A. ve Karalar, H. (2017). Sınıföğretmenliğiöğretim elemanlarının Web 2.0 araçlarına yönelik görüşleri. Trakya Üniversitesi Eğitim Fakültesi Dergisi, 7 (2), 456474. DOI: $10.24315 /$ trkefd.304255

Kurbanoğlu, S. ve Akkoyunlu, B. (2002). Öğretmen adaylarına uygulanan bilgi okuryazarlığı programının etkiliği ve bilgi okuryazarlığı becerileri ile bilgisayar özyeterlik algısı arasındaki ilişki. Hacettepe Üniversitesi Eğitim Fakültesi Dergisi, 22(22), 98-105.

Kuzgun, H. ve Özdinç, F. (2017). Okul öncesi eğitimde teknoloji kullanimina yönelik öğretmen görüşlerinin incelenmesi. Uşak Üniversitesi Sosyal Bilimler Dergisi, 10, 83-102

MEB (2017). Öğretmenlik mesleği genel yeterlilikleri. 15.12 .2020 tarihinde http://oygm.meb.gov.tr/meb iys dosyalar/2017 12/11115355 YYRETMENLYK MESLEYY GENEL YETERLYKLERY.pdf adresinden erişilmiştir. 
Miles, B. M. ve Huberman A. M. (1994). Qualitative data analysis: An expanded source book. California, USA: Sage Publications.

Somyürek, S., Atasoy, B. ve Özdemir, S. (2009). What makes a board smart? Computersand Education, 53(2), 368-374.

Stemler, S. (2000). An overview of content analysis. Practical Assessment, Research and Evaluation, 7(17), 1-6. https://doi.org/10.7275/z6fm-2e34

Taş, H. İ., Özel, A., ve Demirci, A. (2007). Coğrafya öğretmenlerinin teknolojiye bakış açları ve teknolojiden yararlanma seviyeleri. Dumlupınar Üniversitesi Sosyal Bilimler Dergisi, 19, 31-51.

Tutar, M. (2015). Eğitim Bilişim Ağı (EBA) sitesine yönelik olarak öğretmenlerin görüşlerinin değerlendirilmesi. (Yayınlanmamış Yüksek Lisans Tezi). Karadeniz Teknik Üniversitesi Eğitim Bilimleri Enstitüsü, Trabzon.

Üstün, Ç. ve Özçiftçi, S. (2020). Covid-19 pandemisinin sosyal yaşam ve etik düzlem üzerine etkileri: Bir değerlendirme çalışması. Anadolu Kliniği Tıp Bilimleri Dergisi, 25(1), 142-153.

Vural, B. (2004). Ĕ̆itim-öğretimde teknoloji ve materyal kullanimi. İstanbul: Hayat Yayınclik.

Yıldırım, A. ve Şimşek, H. (2003). Sosyal bilimlerde nitel araştırma yöntemleri. Ankara: Seçkin yayıncilik.

Yıldırım, K. (2020). İstisnai bir uzaktan eğitim öğretim deneyiminin öğrettikleri. Alanyazın Eğitim Bilimleri Eleştirel İnceleme Dergisi, 1(1), 7-15.

\section{Kaynakça Bilgisi / Citation Information}

Başaran, M., Ülger, I. G., Demirtaş, M., Kara, E., Geyik, C. ve Vural, Ö.F. (2021). Uzaktan eğitim sürecinde öğretmenlerin teknoloji kullanım durumlarının incelenmesi. OPUS-International Journal of Society Researches, 17(37), 4619-4645. DOI: 10.26466/opus.903870 